\title{
Aplikasi Perhitungan Dan Transaksi Penjualan Rumah Secara Kredit Pada PT. XYZ
}

\author{
M.Reza Fahleta ${ }^{1}$, Rika Kharlina Ekawati, S.E., M.T.I ${ }^{2}$ \\ STMIK GI MDP; Jl. Rajawali No. 14, Palembang, Telepon (0711)376400/fax (0711)376360 \\ Jurusan Komputerisasi Akuntansi, STMIK GI MDP, Palembang \\ e-mail : ${ }^{* 1}$ mrezafahleta@mhs.mdp.ac.id,${ }^{* 2}$ rika@ mdp.ac.id
}

\begin{abstract}
Abstrak
Kebutuhan akan perumahan semakin meningkat di masyarakat. Peluang ini dengan cepat diambil oleh developer perumahan untuk menawarkan penjualan rumah secara tunai maupun kredit. PT XYZ merupakan salah satu developer perumahan yang mengambil kesempatan ini. Tetapi dalam perhitungan transaksi penjualan yang dilakukan masih secara manual. Tujuan dari tugas akhir ini adalah membuat Aplikasi Perhitungan dan Transaksi Penjualan Kredit pada PT XYZ untuk Aplikasi ini dibuat untuk membantu perusahaan untuk melakukan perhitungan dan transaksi penjualan rumah khususnya secara kredit serta memproses data untuk pelaporannya. Metodologi yang digunakan yaitu pemetaan kerangka PIECES dengan beberapa tahapan yaitu Performance, Information, Economic, Control, Efficiency dan Service.Tugas akhir ini menghasilkan aplikasi perhitungan dan transaksi penjualan rumah secara kredit yang telah disesuaikan sesuai kebutuhan perusahaan agar mampu memberikan informasi dan memproses data secara terkomputerisasi.
\end{abstract}

Kata kunci-Aplikasi, Perhitungan dan Transaksi, Penjualan Kredit, PIECES

\begin{abstract}
At present the need for housing is increasing in the community.This opportunity is quickly taken by housing developers to offer home sales in cash and credit. PT XYZ is one of the housing developers who took this opportunity. But in the calculation of sales transactions carried out still manually. The purpose of this final project is to make a Credit Sales Calculation and Transaction Application at PT XYZ for this Application made to help companies make calculations and transactions of home sales, especially on credit and processing data for reporting. The methodology used is mapping of PIECES framework with several stages, namelyPerformance, Information, Economic, Control, Efficiency andService. This final project produces a calculation application and home sales transaction on credit that has been adjusted according to the needs of the company in order to be able to provide information and process data in a computerized manner.
\end{abstract}

Keywords-Application, Calculation and Transaction, Credit Sales, PIECES

\section{PENDAHULUAN}

Derumahan merupakan salah satu kebutuhan pokok manusia yang harus dipenuhi. Perumahan juga merupakan kebutuhan yang bersifat primer.Bagaimana pun kondisi perekonomian yang sedang terjadi, setiap orang harus memiliki tempat tinggal untuk memenuhi salah satu kebutuhan utamanya. Namun harga rumah yang melambung tinggi menyebabkan jarang orang 
mampu membeli rumah secara tunai, sehingga membeli dengan angsuran atau menyewa adalah alternatif yang dapat dipilih.

Penjualan rumah yang ditawarkan oleh para developer melalui 2 cara, yaitu penjualan secara tunai dan kredit. Penjualan Penjualan tunai adalah penjualan bersifat cash and carry yang mana penjualan dilakukan setelah terdapat kesepakatan harga antara penjual dengan pembeli, lalu pembeli dapat membayar secara langsung dan barang dapat langsung dimiliki [1]. Sedangkan penjualan kredit dilaksanakan oleh perusahaan dengan cara mengirimkan barang sesuai dengan order yang diterima dari pembeli dan untuk jangka waktu tertentu perusahaan mempunyai tagihan kepada pembeli tersebut [2]. Untuk menghindari tidak tertagihnya piutang, setiap penjualan kredit yang pertama kali kepada seseorang pembeli selalu didahului dengan analisis terhadap kelayakan pemberian kredit kepada pembeli tersebut.

Kehadiran sistem Kredit Pemilikan Rumah (KPR) sangat dibutuhkan oleh masyarakat yang penghasilan ekonominya kelas menengah ke bawah. Berbagai upaya yang dilakukan pemerintah untuk pembangunan perumahan yang layak huni antara lain pembangunan Rumah Sederhana (RS) dan Rumah Sangat Sederhana (RSS). Pembangunan yang di biayai melalui fasilitas kredit merupakan program dari bank untuk memenuhi kebutuhan masyarakat akan perumahan untuk tempat tinggal, baik itu masyarakat berpenghasilan rendah, menengah, maupun penghasilan tinggi angsuran [3].

Dari hasil survey awal untuk pengajuan kredit di PT XYZ terdapat kendala dalam proses pengajuan kredit. Dalam proses perhitungan yang dilakukan masih secara manual, yaitu proses pendataan angsuran untuk kreditur masih menggunakan buku catatan angsuran. Sehingga bagian administrasi yang mengolah data penjualan dan angsuran harus mencatat dalam buku tersebut untuk membuat laporan penjualan. Simulasi perhitungan kredit rumah juga masih dilakukan secara manual, sehingga kreditur tidak bisa melihat langsung bagaimana proses perhitungan kredit dengan akurat.

Dari kendala tersebut, memerlukan bantuan aplikasi untuk lebih mempercepat proses dalam perusahaan sehingga dapat menghemat waktu dan kinerja. Aplikasi adalah terapan yang difungsikan secara khusus dan terpadu sesuai kemampuan yang dimilikinya [4]. Dengan adanya aplikasi dapat membantu proses perhitungan dan penjualan rumah secara kredit sehingga lebih mudah dalam perhitungan dan proses pengajuan kredit.

Dari beberapa penelitian yang telah dilakukan terkait dengan penjualan diantaranya, Penelitian Suwarni Amelia [5] yang berjudul "Aplikasi perhitungan Kredit Mobil pada PT. Procar Finance Palembang."Menganalisis tentang perhitungan kredit angsuran mobil.Metode analisis yang digunakan Iterative.Hasilnya menunjukan bahwa sistem penjualan masih dilakukan secara manual, sehingga untuk mengatasinya maka di buat Aplikasi Perhitungan Kredit Mobil.

Selanjutnya hasil penelitian Isnaini Irawati [6] yang berjudul "Komputerisasi Penjualan Sepeda Motor Secara Kredit pada Dealer Endra Motor Sunggingan Boyolali."Metode analisis yang digunakan System Development Life Cycle. Menganalisis tentang keakuratan perhitungan kredit bulanan dan ketepatan waktu dalam menyajikan informasi pencatatan stok motor, hasilnya menunjukkan bahwa perhitungan kredit bulanan masih membutuhkan waktu yang lama dalam setiap kali transaksi penjualan secara kredit dalam penentuan nominal yang harus dibayarkan dalam angsuran bila dilakukan secara manual. Sehingga untuk mengatasi masalah tersebut dibuat Aplikasi Transaksi Penjualan Motor Secara Kredit.

\section{METODE PENELITIAN}

Metode penelitian yang digunakan yaitu menggunakan analisis sistem menggunakan kerangka PIECES (Performance, Information, Economics, Control, Efficiency, Services) untuk 
melihat permasalahan yang terjadi pada PT. XYZ. Kemudian akan dirancang aplikasi yang seseuai dengan kebutuhan perusahaan.

\subsection{Analisis Permasalahan}

Analisis permasalahan dilakukan dengan menggunakan kerangka PIECES.Metode PIECES merupakan suatu kerangka kerja yang digunakan untuk klasifikasi permasalahan yang ada berdasarkan kriteria: Performance, Information, Economic, Control, Efficiency dan Service [7]. Adapun permasalahan yang ada dengan menggunakan kerangka PIECES yang telah dihimpun adalah sebagai berikut:

Tabel 1. Permasalahan Dengan Kerangka PIECES

\begin{tabular}{|l|l|}
\hline PIECES & \multicolumn{1}{c|}{ Permasalahan } \\
\hline Performance & $\begin{array}{l}\text { Kesulitan dalam menyajikan informasi perhitungan pengajuan } \\
\text { kredit karena data yang ada masih berupa berkas. }\end{array}$ \\
\hline Information & $\begin{array}{l}\text { Proses penyajian simulasi untuk perhitungan kredit masih } \\
\text { menggunakan cara manual sehingga konsumen sulit untuk } \\
\text { mendapatkan informasi yang rinci untuk mengajukan kredit. }\end{array}$ \\
\hline Economic & $\begin{array}{l}\text { Dalam pencatatan penjualan dan angsuran masih banyaknya } \\
\text { penggunaan berkas dokumen yang bertumpuk dan tidak } \\
\text { disimpan secara teratur. }\end{array}$ \\
\hline Control & $\begin{array}{l}\text { Kesulitan dalam merekapitulasi data laporan penjualan dan } \\
\text { angsuran dalam menghitung jumlah yang telah diterima } \\
\text { dikarenakan proses perhitungan yang dilakukan satu persatu. }\end{array}$ \\
\hline Efficiency & $\begin{array}{l}\text { Penyimpanan berkas konsumen dan pembayaran angsuran } \\
\text { membutuhkan banyak buku menyebabkan banyaknya waktu } \\
\text { yang dibutukan untuk rekapitulasi dan biasa terjadi kesalahan } \\
\text { dalam pencatatan. }\end{array}$ \\
\hline Service & $\begin{array}{l}\text { Dalam melakukan rekap penjualan atau pun angsuran masih } \\
\text { kesulitan untuk mencari data satu persatu dikarenakan data } \\
\text { dalam dokumen atau buku yang tertumpuk. }\end{array}$ \\
\hline
\end{tabular}

\subsection{Analisis Proses}

Analisis proses yang dilakukan menggunakan Data Flow Diagram (DFD) dengan menggunakan diagram konteks dan diagram nol.

a. Diagram Konteks

Diagram konteks digunakan untuk menggambarkan relasi relasi antara sistem.

Diagram tersebut tidak memuat penyimpanan data dan tampak sederhana untuk diciptakan, begitu entitas-entitas eksternal serta aliran data menuju dan dari sistem diketahui penganalisis dari wawancara dengan pengguna dan sebagai hasil analisis dokumen [8]. Berikut adalah diagram konteks sistem yang sedang berjalan pada PT. XYZ: 


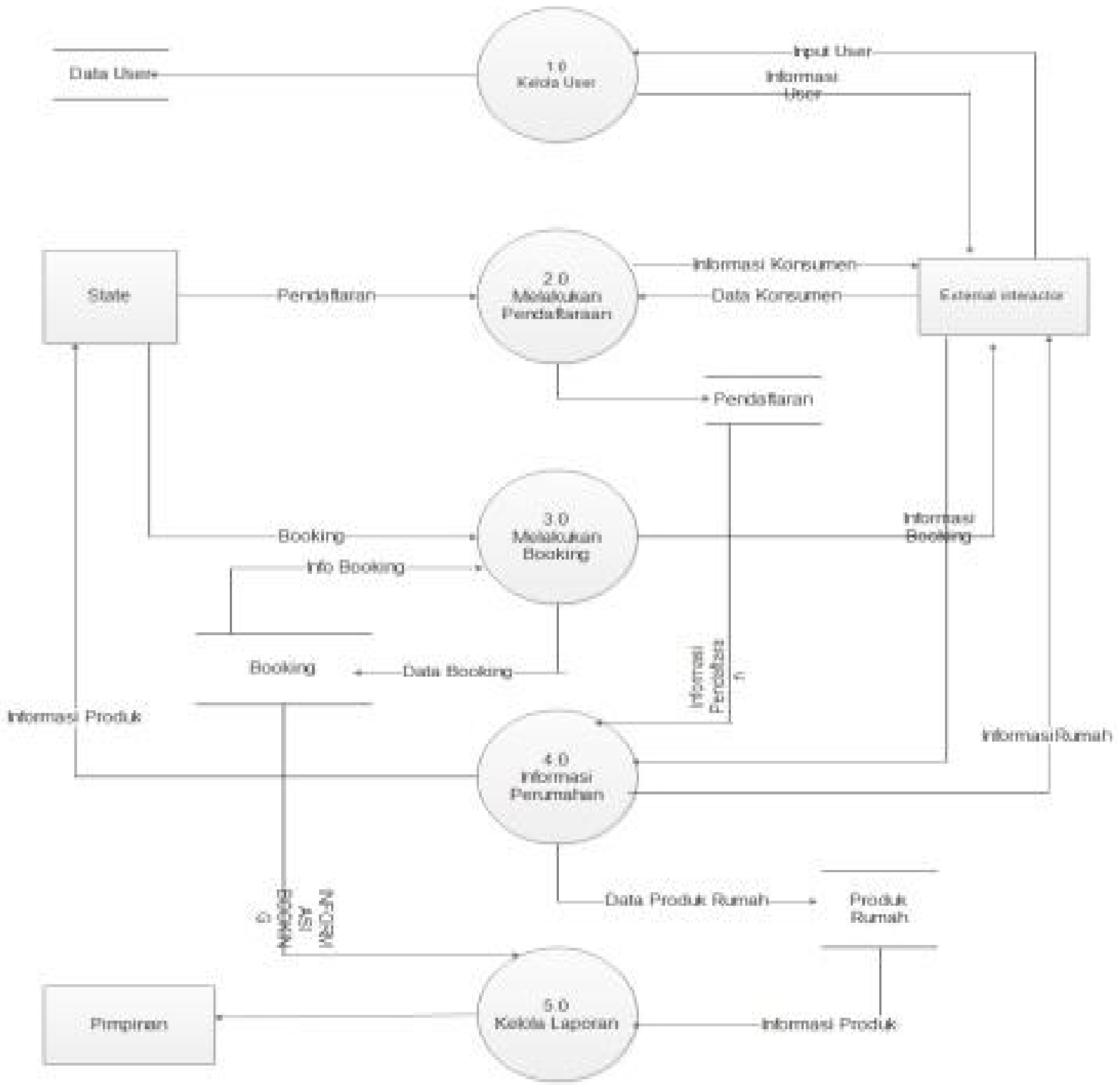

b. Diagram Nol

Gambar 1. Diagram Konteks Sistem yang Berjalan

Diagram Nol sistem yang berjalan pada PT. XYZ dapat dilihat pada gambar 1: 


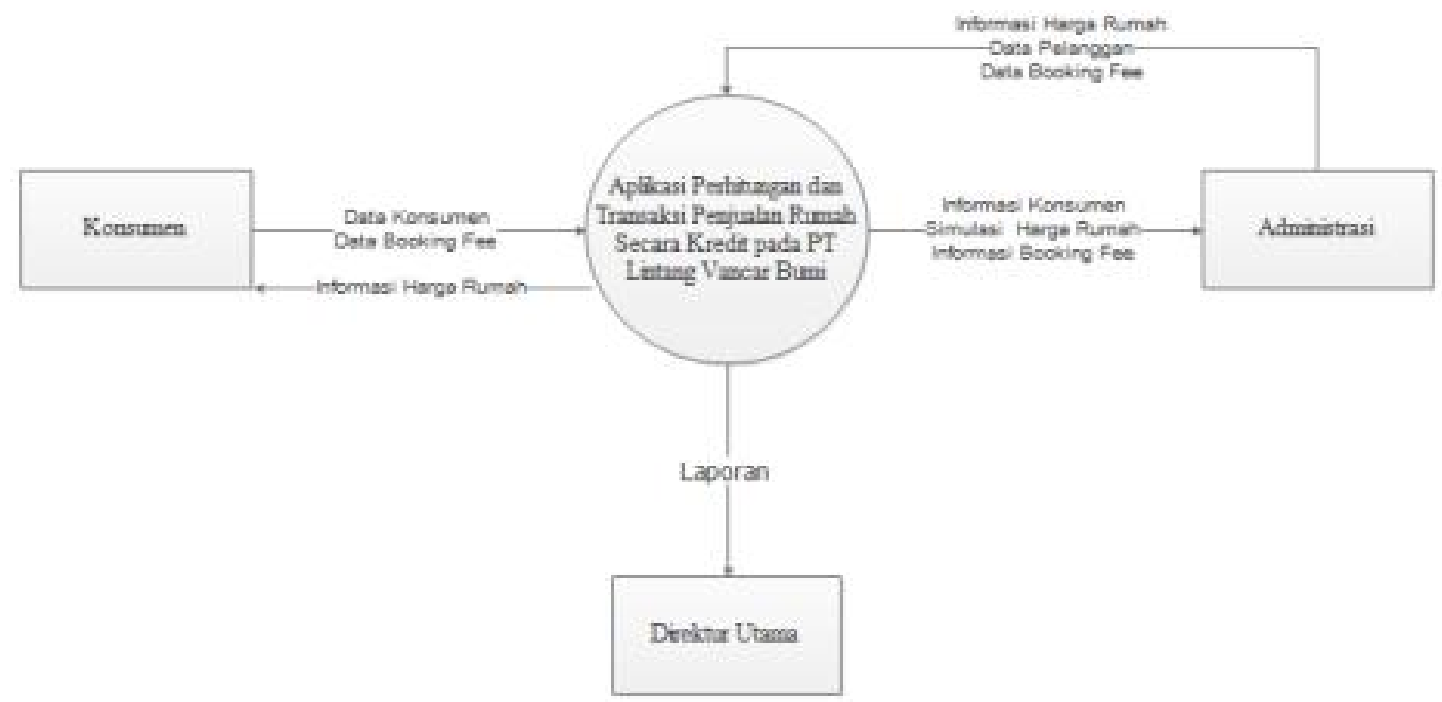

Gambar 2. Diagram Nol Sistem yang Berjalan

\subsection{Rancangan Proses}

Rancangan proses menggunakan Data Flow Diagram (DFD) dalam perancangannya. Data Flow Diagram (DFD) merupakan diagramyang menggunakan notasi-notasi untuk menggambarkan aliran data secara logis dari sistem [9]. Sedangkan menurut Rosa [10] Data Flow Diagram adalah representasi grafik yang menggambarkan aliran informasi dan transformasi informasi yang diaplikasikan sebagai data yang mengalir dari masukan (input) dan keluaran (output).

Data Flow Diagram (DFD) dari sistem yang diusulkan adalah sebagai berikut: 


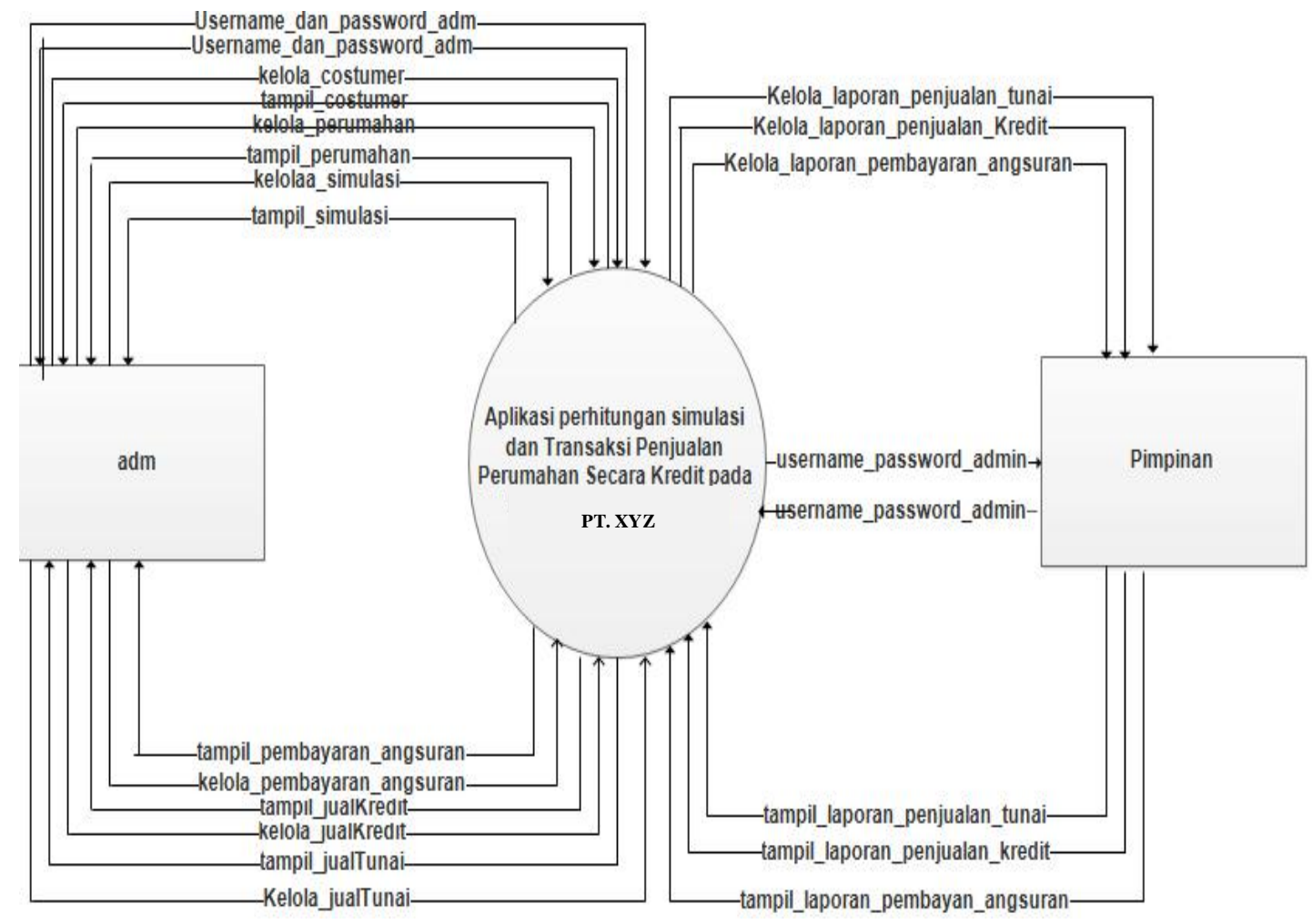

Gambar 3. Diagram Konteks Sistem yang Diusulkan

\section{HASIL DAN PEMBAHASAN}

Hasil dan pembahasan dari analisis yang telah dilakukan yaitu berupa implementasi berupa aplikasi yang dapat membantu perusahaan dalam memberikan layanan terbaik bagi para konsumennya. Adapun pembahasan dari analisis ini berupa rancangan tampilan antarmuka dari aplikasi yang akan digunakan oleh PT. XYZ.

3.1. Rancangan Layar

\section{Login}

Rancangan form Login merupakan tampilan menu awal pada saat memasuki menu utama pada aplikas idengan memasuki Username, Jabatan, Password. Berikut tampilan pada saat login yang dapat dilihat pada gambar 4 . 


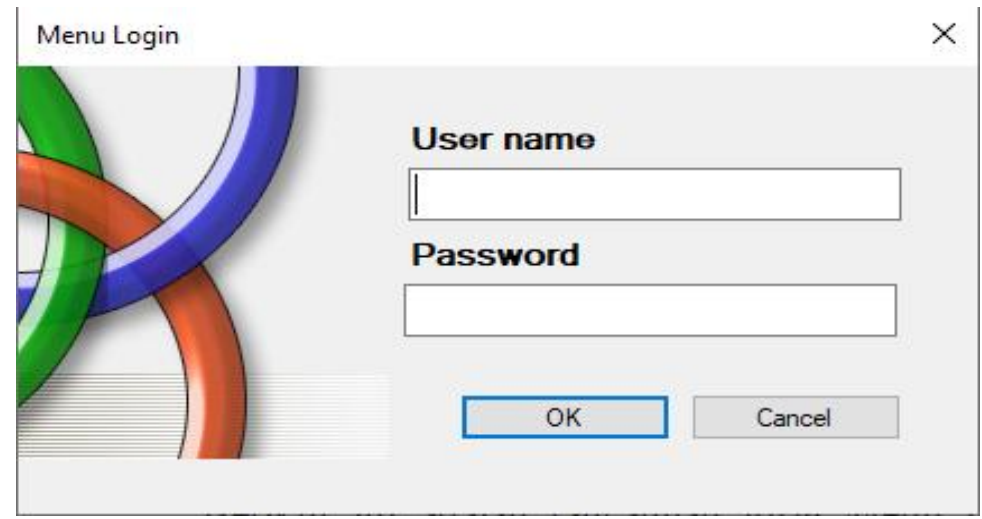

Gambar 4. Tampilan Form Login

2. Form Menu Utama

Form menu utama merupakan form yang menunjukkan semua menu yang dirancang pada aplikasi ini, antara lain: Master, Transaksi, Setting Laporan dapat dilihat pada gambar 5 .

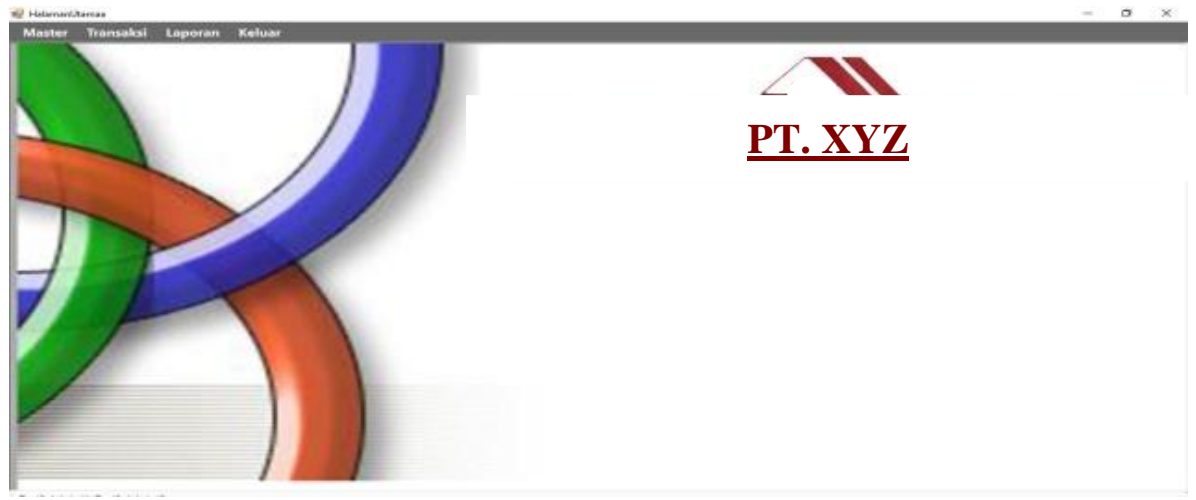

Gambar 5. Tampilan Form Menu Utama

\section{Form Tambah Pengguna}

Form tambah pengguna merupakan untuk tambah pengguna baru. Berikut tampilan Form Tambah Pengguna yang dapat dilihat pada gambar 6

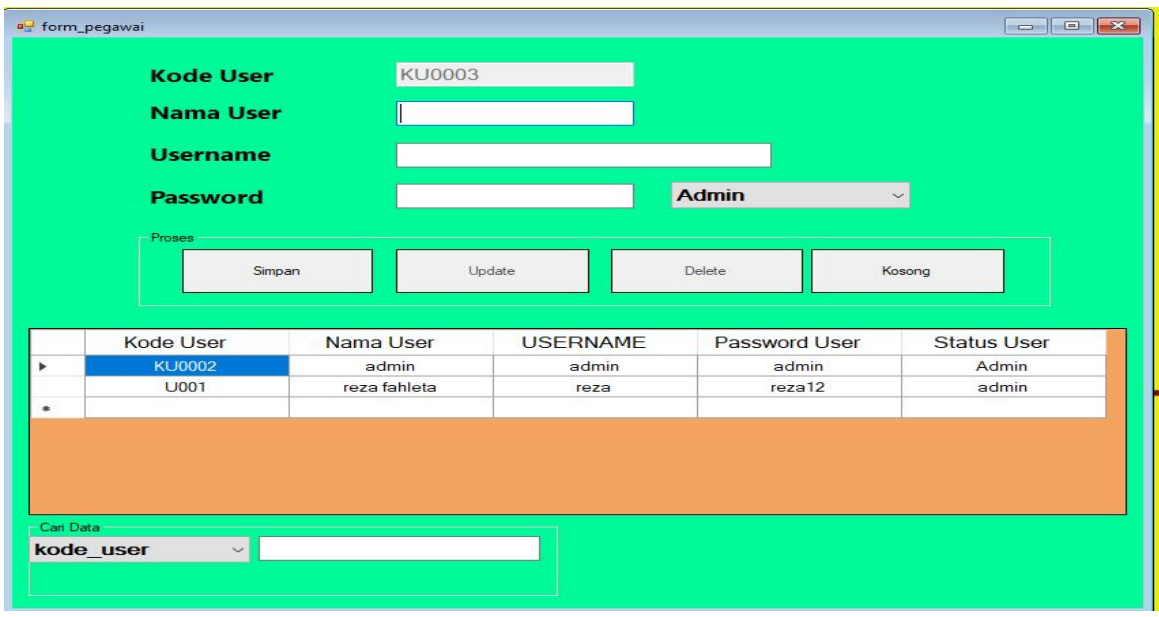

Gambar 6. Tampilan Form Tambah Pengguna

Fahleta, et.al (Aplikasi Perhitungan dan Transaksi Penjualan Rumah Secara Kredit pada PT. XYZ) 


\section{Form Tambah Costumer}

Rancangan form digunakan untuk tambah pelanggan yang terdiri dari Kode Pelanggan, Nama Pelanggan, Alamat Pelanggan, No. Telepon. Berikut tampilan form pelanggan yang dapat dilihat pada gambar 7.

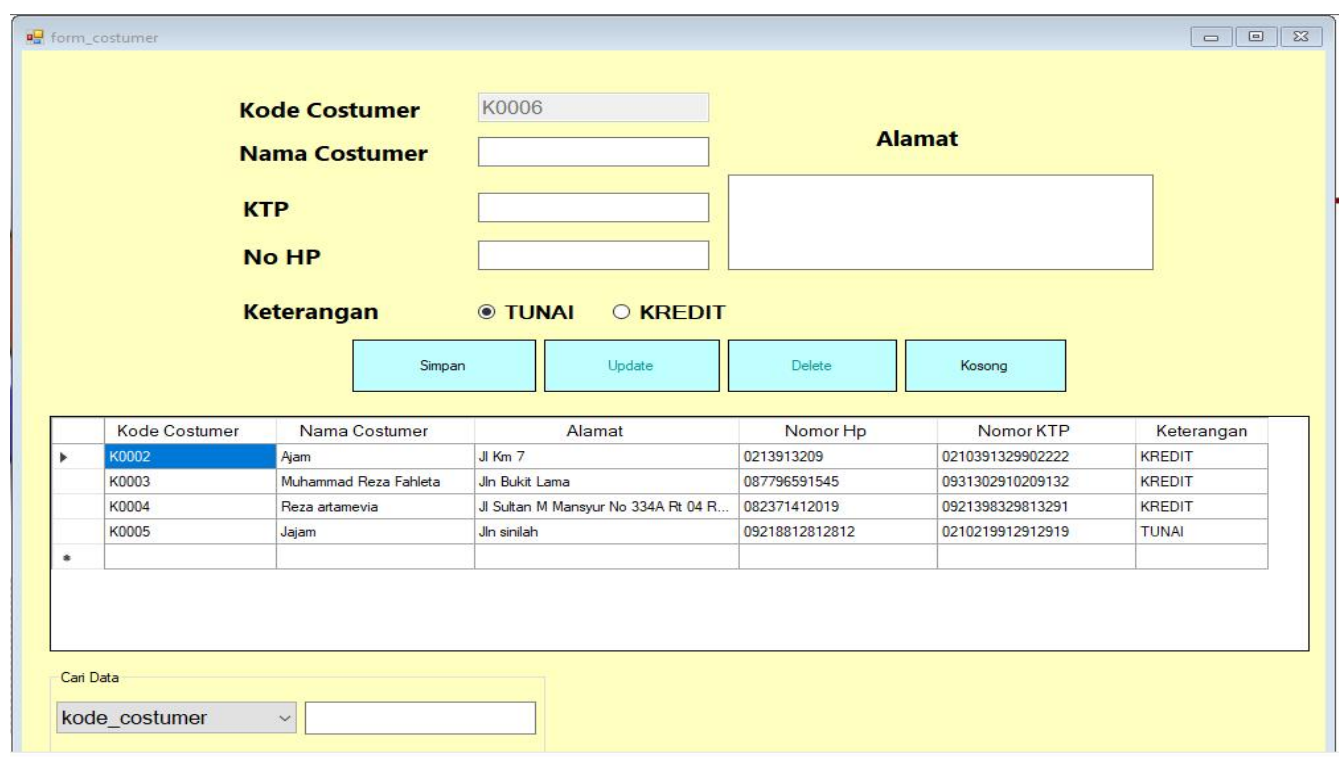

Gambar 7. Tampilan Form Tambah Pelanggan

\section{Form Perumahan}

Rancangan Form perumahan yang menunjukkan tampilan daftar perumahan. Dapat dilihat pada gambar 8.

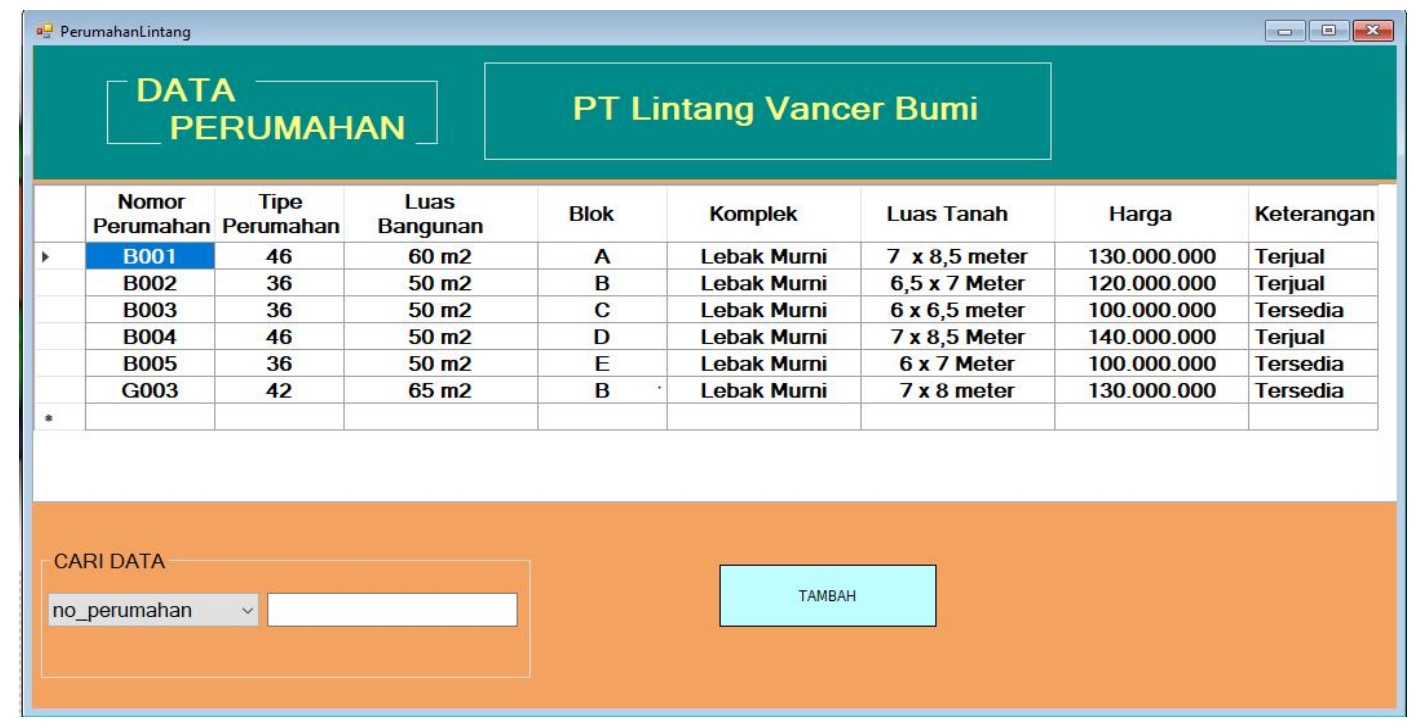

Gambar 8. Form Perumahan

\section{Form Simulasi}

Rancangan Form Simulasi yang menunjukkan proses perhitungan kredit perumahan, dapat dilihat pada gambar 9 . 


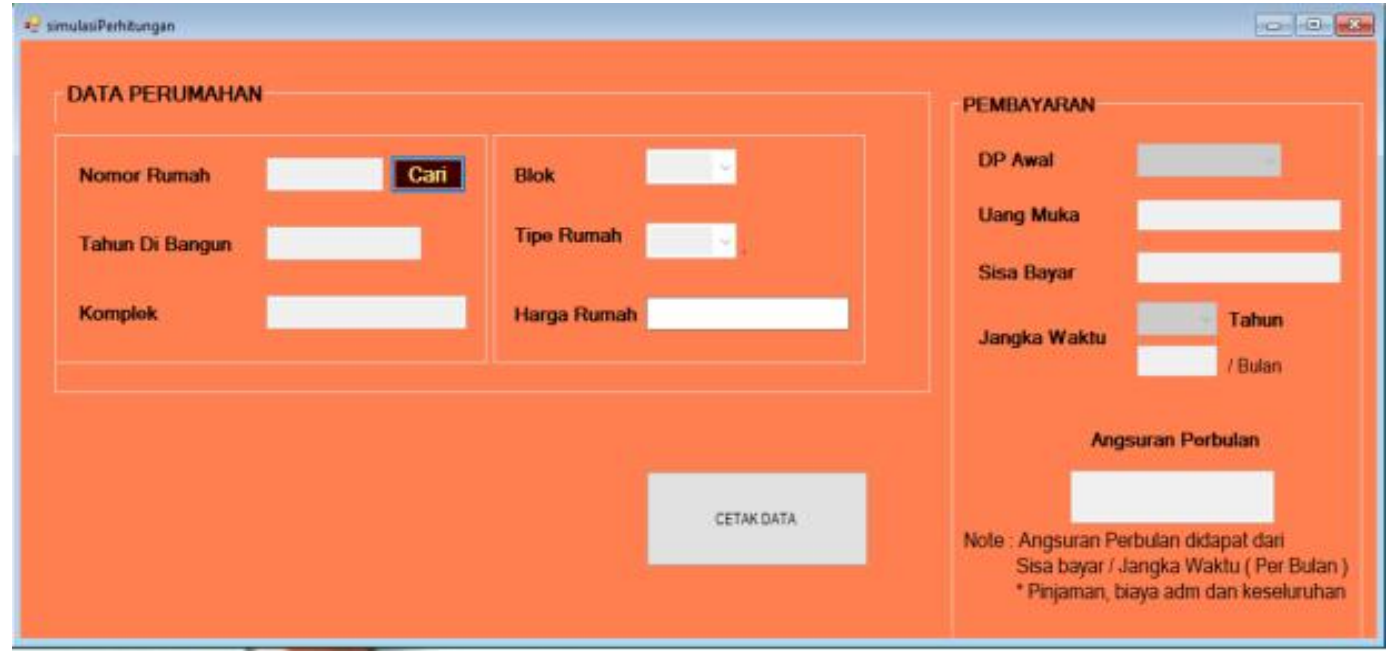

Gambar 9. Form Simulasi

\section{Form Penjualan Tunai}

Form penjualan tunai yang menunjukkan proses mendata penjualan rumah secara tunai ke pihak costumer. Dapat dilihat pada gambar 10.

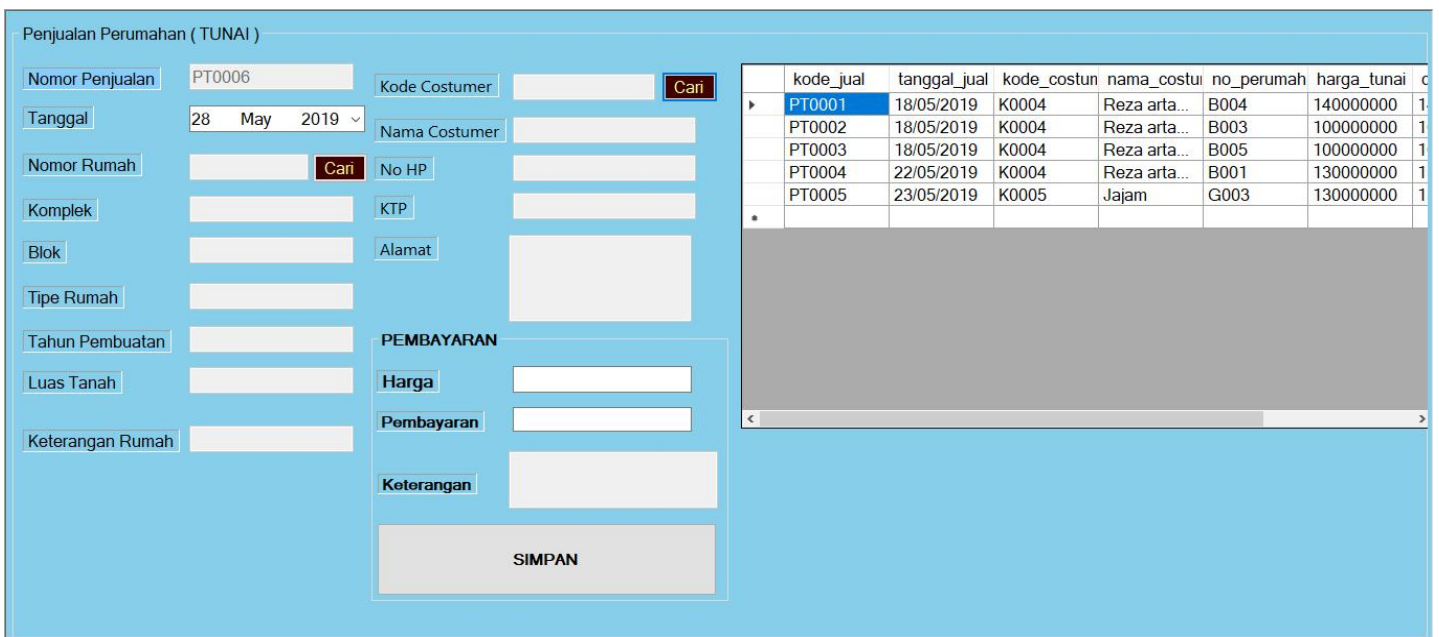

Gambar 10. Form Penjualan Tunai

\section{Penjualan Kredit}

Form Penjualan yang menunjukkan tampilan daftar transaksi penjualan kredit. Dapat dilihat pada gambar 11 dan 12. 


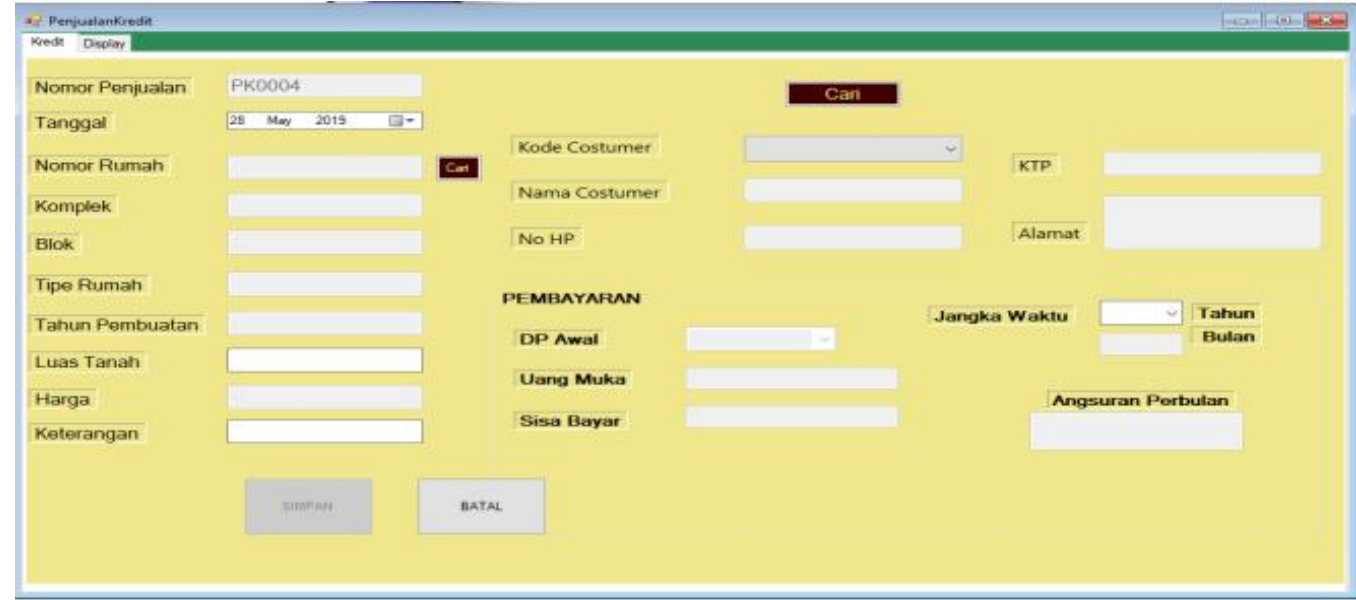

Gambar 11. Form Gaji

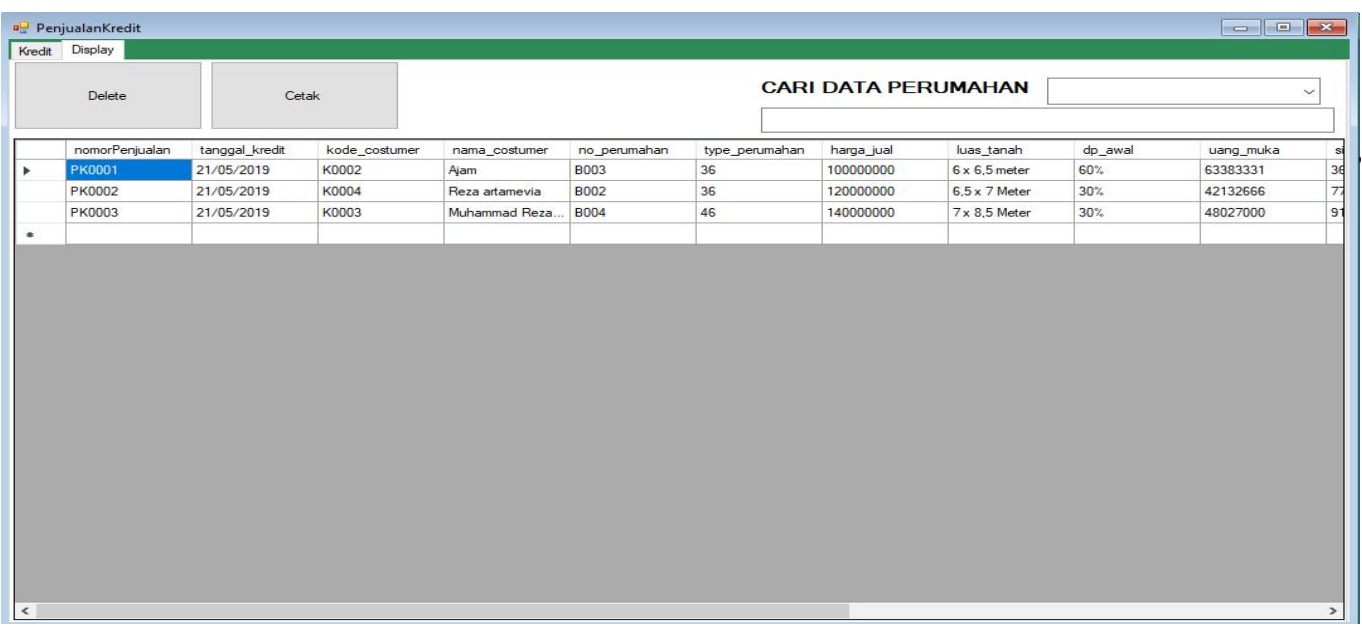

Gambar 12. Form Penjualan Kredit

\section{Form Pembayaran Angsuran}

Berikut ini adalah rancangan form Pembayaran Angsuran yang menunjukan tampilan mencari data pengguna dan laporan cetak pembayaran dapat dilihat pada gambar 13 dan 14. 


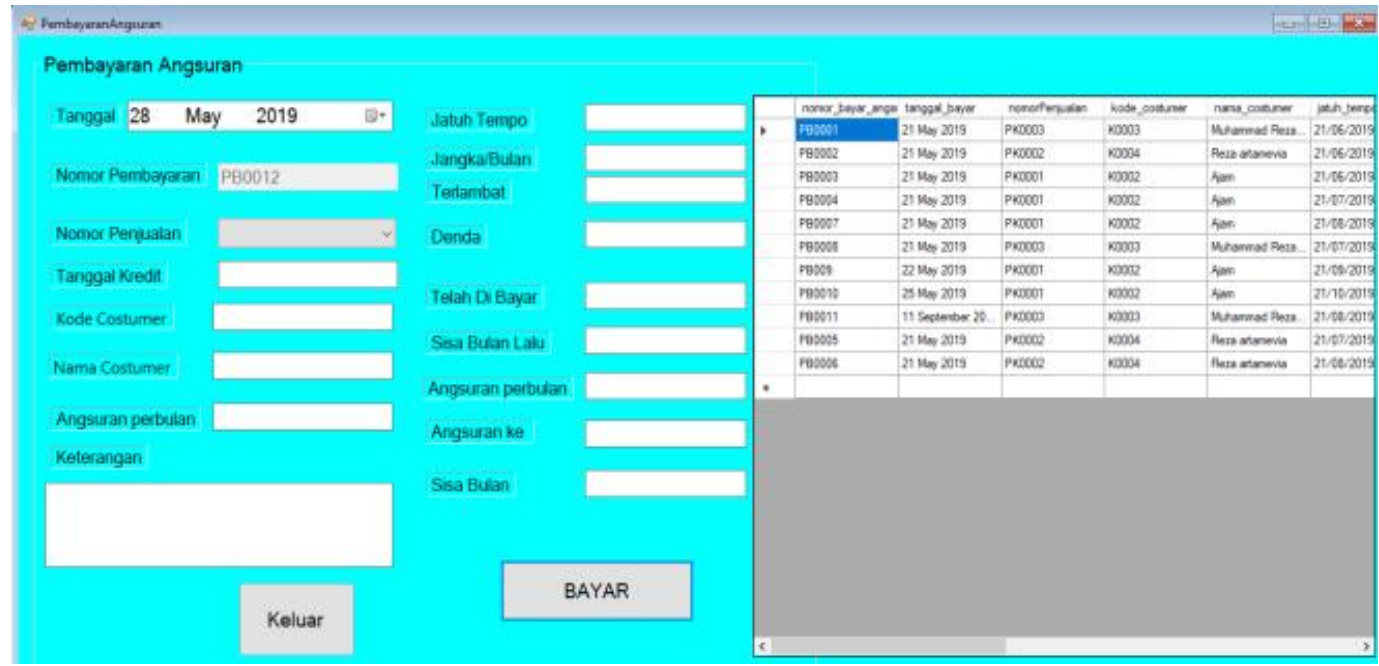

Gambar 13. Form Pembayaran Angsuran

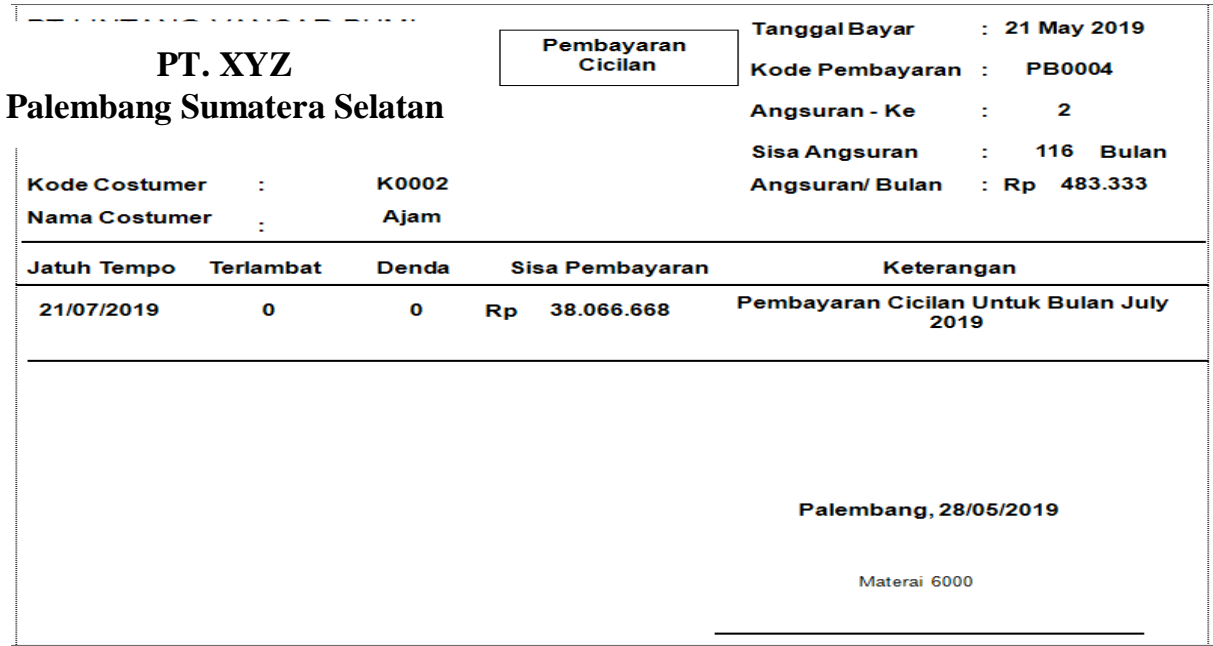

Gambar 14. Laporan Angsuran

\section{Form Cetak Penjualan Tunai (Periode)}

Berikut ini adalah rancangan form Penjualan Tunai (periode) yang menunjukan tampilan laporan penjualan perperiode dapat dilihat pada gambar 15 . 


\begin{tabular}{|c|c|c|}
\hline PT. XYZ & TanggalCetak: 28/05/2019 \\
$\begin{array}{c}\text { Palembang, } \\
\text { Sumatera Selatan }\end{array}$ & PT. XYZ & \\
\hline
\end{tabular}

Laporan Penjualan Kredit

Periode 28/04/2019. 28/05/2019

\begin{tabular}{|c|c|c|c|c|c|c|c|c|}
\hline Nomor Penjualan & Tanggal & Nama & No Rumah & Harga Rumah & DP AWAL & Uang Muka & Sisa Bayar & Tahun \\
\hline PK0001 & $21 / 05 / 2019$ & Ajam & B 003 & $100.000 .000,00$ & $60 \%$ & $63.383 .331,00$ & $36.616 .669,00$ & 10 \\
\hline PK0002 & $21 / 05 / 2019$ & Reza artamevia & B002 & $120.000 .000,00$ & $30 \%$ & $42.132 .666,00$ & $77.867 .334,00$ & 5 \\
\hline PK0003 & $21 / 05 / 2019$ & Muhammad Reza Fahleta & B004 & $140.000 .000,00$ & $30 \%$ & $48.027 .000,00$ & $91.973 .000,00$ & 5 \\
\hline
\end{tabular}

Gambar 15. Laporan Penjualan Kredit

\section{KESIMPULAN}

Berdasarkan hasil analisis yang telah dilakukan, maka ditarik kesimpulan untuk memecahkan masalah yang ada di perusahaan yang dapat berguna bagi PT XYZ:

1. Aplikasi Simulasi dan Transaksi Penjualan Rumah yang telah dibuat dapat membantu proses perhitungan untuk pengajuan kredit rumah secara akurat dan konsumen bisa melihat langsung simulasi perhitungan kredit rumah.

2. Dengan adanya aplikasi ini dapat membantu menyimpan data konsumen sehingga memudahkan perusahaan untuk mencari data.

3. Aplikasi ini dapat membantu perusahaan dalam merekap data pembayaran angsuran sehingga perusahaan dapat dengan mudah melihat catatan pembayaran per konsumen.

\section{SARAN}

berikut:

Adapun saran yang disampaikan pada perusahaan PT XYZ yaitu adalah sebagai

1. Sebaiknya pihak perusahaan PT. XYZ melakukan pelatihan kepada karyawan dalam mengoperasikan aplikasi ini sehingga karyawan lebih mudah dalam menguasai sistem yang terkomputerisasi.

2. Untuk pengembangan aplikasi ke depannya diharapkan sistem yang digunakan PT XYZ menggunakan website agar konsumen bisa melihat simulasi serta detail rumah yang ingin dibeli oleh konsumen.

\section{DAFTAR PUSTAKA}

[1] Anthony, A., Tanaamah, A. R., \& Wijaya, A. F. 2017, Analisis dan Perancangan Sistem Informasi Penjualan Berdasarkan Stok Gudang Berbasis Client Server (Studi 
Kasus Toko Grosir “Restu Anda”). Jurnal Teknologi Informasi dan Ilmu Komputer, 4(2), 136-147.

[2] Mulyadi, T 2016, Sistem Akuntansi Edisi 4, Salemba Empat, Jakarta

[3] Fitrianto, B, 2012, Latar Belakang Kredit Pemilikan Rumah (KPR).

[4] Sutabri, T 2012, Analisis Sistem Informasi, Andi, Yogyakarta.

[5] Suwarni, A., \& Sari, A. N. 2013, Aplikasi Perhitungan Kredit Mobil pada PT. Procar Finance Palembang.

[6] Irawati, I. and KR, R.M.A. 2015, Komputerisasi Penjualan Sepeda Motor Secara Kredit pada Dealer Endra Motor Sunggingan Boyolali, IT CIDA, 1 (1).

[7] Yodi, Y. 2017, Analisis Sistem Informasi Akademik Mahasiswa pada STMIK Gici Batam Menggunakan Metode Pieces, Jursima, 5 (2), 37-45.

[8] Kendall, K. E., dan Kendall, J. E. 2010, Analisis dan Perancangan Sistem. PT Indeks, Jakarta.

[9] Fadlil, A., Firdausy, K. and Hermawan, F. 2008, Pengembangan Sistem Basis Data Presensi Perkuliahan Dengan Kartu Mahasiswa Ber-barcode, Telkomnika, 6 (1), p.65.

[10] Rosa, A.S. dan Shalahuddin, M. 2013, Rekayasa Perangkat Lunak Terstruktur dan Berorientasi Objek, Informatika, Bandung. 